Psychology of Language and Communication 2014, Vol. 18, No. 3

DE DEGRUYTER

OPEN

DOI: $10.2478 /$ plc-2014-0015

\author{
HRISTO KYUCHUKOV
}

St. Elizabeth University, Bratislava

\title{
ACQUISITION OF ROMANI IN A BILINGUAL CONTEXT
}

\begin{abstract}
The paper presents research findings from research on Roma children and their acquisition of different grammatical categories in the Romani language. Results from three different studies with Roma children from Bulgaria are discussed: acquisition of mental state verbs (MSV), Bates-MacArthur Communicative Development Inventories (CDI) in Romani and subtests from DELV (Seymour, Roeper, \& de Villiers, 2005). All the testing and research shows that Roma children follow the paths of normally developing children in their language development. Roma children are able to correctly use nouns, verbs, wh-questions and to assume different communicative roles.
\end{abstract}

Key words: Romani, acquisition, language development

\section{Introduction}

As a point of departure I take the ideas of Babska and Shugar (1986) which see the child as a learner of a language through activities and also developing its language skills in activities (see also Shugar, Bokus, \& Smogorzewska, 2013). This concept is very important for the language development of Roma children as well, because they learn the language mainly by being involved in community activities planned by their parents and other adults in accordance with the cultural specificities of Roma.

Fidanka is a small Roma girl from Bulgaria. She is 2 years and 10 months old (hereafter 2;10) and lives in one of the big Roma ghettos of Sofia. She is being raised by an extended family. Her parents (both with a university degree) live together with the parents of the father and with the family of his older brother. All three families (the parents, the grandparents and the uncle's family) take care

Address for correspondence: Hristo Kyuchukov, St. Elizabeth University, P.O. Box 104, 81000 Bratislava, Slovakia. E-mail: hkyuchukov@gmail.com 
of Fidanka. All the members of the extended family talk to Fidanka in Romani and in Bulgarian. There are activities where they use Bulgarian, but most of the time they speak Romani to her.

As a result of being surrounded by these languages, she knows which language to use in different situations speaking to the family members. Fidanka started to speak Bulgarian at the age of 2 years and 4 months.

Now speaking Bulgarian or Romani, she produces sentences which are mixed: For example:
(1) Чакай малко (В)
$\operatorname{akana}(R)$
да видиш (B)
wait a bit (B) now $(\mathrm{R})$
to see $(\mathrm{B})$
Wait a bit you will see it now.

In this sentence the matrix language is Bulgarian. Speaking Bulgarian the child embeds a Bulgarian word.
(2) Dikh o čho
so $(R)$
удари ме (B)
look the boy
what $(\mathrm{R})$
hit - 3sgPT me (B)
Look the boy that hits me.

The matrix language of the second sentence is Romani, but the child embeds Bulgarian words in the Romani sentence as well.

Thousands of Roma children in Europe grow up in such surroundings - bilingual or multilingual. However, studies on Roma children's bilingualism and multilingualism are limited in the scientific literature. The first publications on Roma children's language development appeared in the 1990s, there have been but a small number of articles on this in the linguistic and psycholinguistic literature (Reger \& Gleason, 1991; Gleason, 1992; Reger, 1999).

My own studies deal with the issues of acquisition of Romani in bilingual/ and trilingual situations (Kyuchukov, 2014, 2011, 2010, 2007, 2005, 1999, 1998; Kyuchukov \& de Villiers, 2009, 2014). Some 15 years ago, I started a longitudinal study with four Roma children ( 2 boys and 2 girls) between the ages of 1;1 and $2 ; 8$ living in one of the biggest Roma settlements in Sofia, Bulgaria. The children were audio-recorded every two weeks by a Roma woman, a member of the same Roma community. I observed the strategies used by the adults in introducing Romani language. Later I made a study trip to New Delhi, India and I observed the strategies used by parents introducing a variety of the Rajasthani language to a girl (2;2 years old) in a "Gypsy" family of smiths who live in the environs of New Delhi. The communication between the parents and the child was videorecorded. From the comparison between the two groups of parents (Roma and Indian), I found exactly the same strategies in the Child Directed Speech which had not been described in the Western scientific literature. 
In her study with Kaluli children, B. Schiefellin (1985) describes a strategy which is called "say after me." Among Roma parents there is a similar strategy: the adult asks for an object and the child has to find it among other objects, without any explanations from the adult. The Indian mother cooking a meal asks her 2-year-old daughter to give her a spoon or a knife, without pointing to it or naming it. The strategies used by the Indian mothers and in the Roma families are very similar.

Other strategies used are learning the language through fairy tales, songs, riddles, teasing and jokes. The language environment of Roma children is extremely rich. Usually they grow up in an extended family where everyone, the whole community in effect, takes care of the child. Roma men play an important role in the language development of children. In their communication with children, Roma mothers use "baby talk", but not Roma fathers. They are the ones who introduce the full range of grammar. In the literature this is known as "a bridge theory" (Gleason, 1975). The fathers and the other members of the Roma family, speaking to the child as an adult from a very early age, actually introduce the whole grammar of the language. On the other hand, the use of different strategies like learning songs together, telling fairy tales, and teasing also introduces the grammar of Romani.

\section{The Study}

The aim of the present paper is to show how Roma children acquire Romani grammatical categories from a very early age in a bilingual context.

The research questions in this study are:

1. Do Roma children actually learn the grammar of the Romani language or is this rather a mixture between two or threelanguages, withoutany grammaticalrules?

2. Which grammatical categories are learned earlier and why, i.e. sequencing?

Three studies were conducted for the purpose of this paper.

Study 1 presents an investigation among young children and their knowledge of mental state verbs.

Study 2 presents a study with Roma parents on Roma children's knowledge of different grammatical categories (verbs and wh-words), using Bates-MacArthur Communicative Development Inventories (CDI).

Study 3 is focused on the communicative competence of Roma children between the ages of 3 and 11 years old in the Romani language.

\section{Findings}

\section{Study 1. Acquisition of Mental State Verbs}

In a large-scale study, Ruffman, Sade and Crowe (2002) examined mothers' mental state language and its role in the development of children's Theory of Mind, and how children's utterances about desires precede their utterances about 
thoughts and act as a training ground for Theory of Mind. The authors identify those verbs as mental state verbs which show:

- Mental state - the verbs think, know

- Emotions

- Physical state

- Sense

- Desire

The total number of these verbs for English is approximately 80 .

A study was conducted with two Roma children from the Fakulteta ghetto settlement in Sofia. The adult-child conversations were audio-recorded in the natural environment of the children in their homes. A boy Kocho (2;3 years old) and a girl Saly (2;2 years old) were the object of my observations. The following example (3) details a Roma adult-child conversation; the mental state verbs in the language of the adult and the child used in this conversation are indicated in bold:

(3) Kocho (2;3) E, he went to buy a balloon.

Adult: But he does not love you, he loves me.

He loves me, does not love you.

Child: He does not love you.

Adult: He loves me.

Child: He does not love you.

Adult: And he does not love you.

Child: Look what it does. (pointing to something)

Adult: You are ugly, this is why Nachko does not love you.

Kocho, do you listen to me?

Child: Here my hand, it hurts.

Adult: You- ugly, me- beautiful, this is why he loves me- Nachko.

Child: I will cry.

Adult: Cry, he loves me and my son Stefcho.

He does not love you.

Child: Look, my hand, hearts.

Adult: Let's bring you to a doctor.

Child: My hand.

Adult: Let's go to a doctor. Do you want to go to a doctor?

Come, outside it is snowing. What is happening outside, my son?

Child: Let me look. I want to look.

The conversation shows very interesting communication strategies by the adult and the child. The adult who is teasing the child uses many mental state verbs. The child, in order to defend himself and to get what he wants as a strategy, changes the topic of the conversation, pointing to his hand and telling the adult 
Table 1. Total $\mathrm{N}$ of utterances

\begin{tabular}{cc}
\hline Child & N of utter. \\
\hline Kocho & 2.088 \\
Saly & 1.313 \\
\hline
\end{tabular}

that his hand hurts. It is obvious that the adult is playing a game with the child and looking at how the child will react. The reaction of the child is to repeat or use the same mental state verbs which the adult says. Table 1 shows the total number of utterances used by the children.

It is obvious that Kocho is more talkative and has a much greater number of utterances, namely 2,088, while Saly has 1,313 utterances. How many mental state verbs are present in the total number of utterances? This is shown in Graph 1.

Graph 1. Mental state verbs (MSV) in \% out of total N of utterances

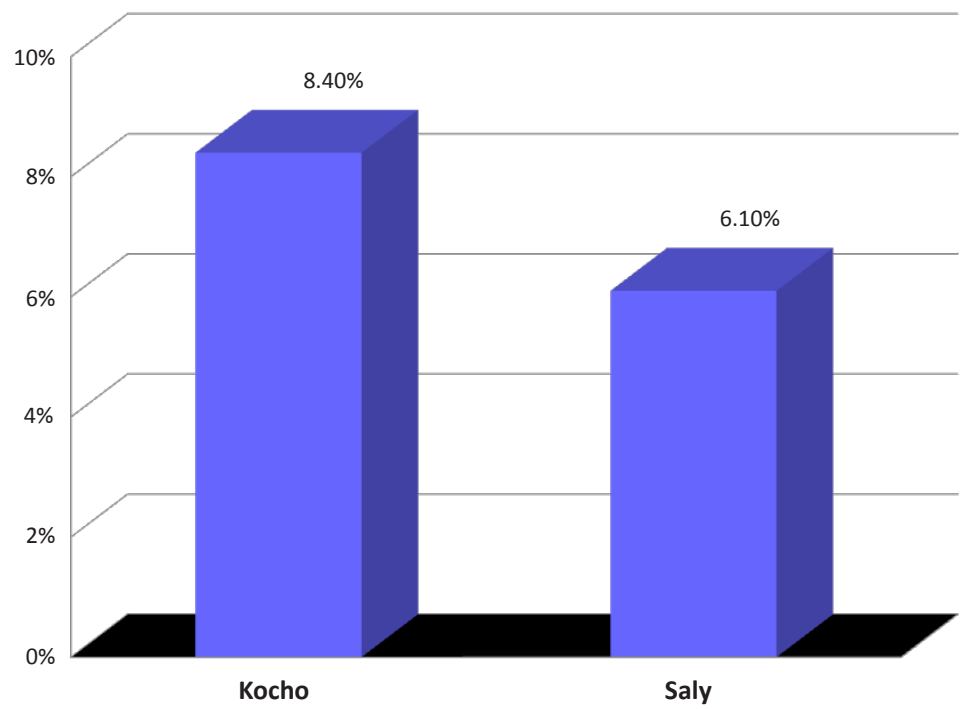

Kocho uses $8.4 \%$ mental state verbs in his communication with adults and Saly $-6.1 \%$. The differences between the used verbs are statistically significant: $t(12)=3.75$, and $t$-critical $=3.34(p<0.001)$. It is interesting to see in which lan- 
Table 2. Mental state verbs (MSV) in Romani and in Bulgarian

\begin{tabular}{lcc}
\hline & Romani & Bulgarian \\
\hline Kocho & 178 & 0 \\
Sally & 65 & 15 \\
\hline
\end{tabular}

guage the children use the mental state verbs. Do they also use Bulgarian mental state verbs and to what extent? The findings are shown in Table 2.

At this stage of language development of the children, the mental state verbs most often used by the children are those which show some emotions, desire or physical state: dehav (I love), mangav (I want), dukhal (it hurts). On the other hand, the children do not use any verbs which show mental states such as think or know.

In the language of both children, Romani mental state verbs dominate. Kocho by the age of 2;3 is still monolingual, but Saly is already acquiring knowledge in Bulgarian. In Saly's language, $19 \%$ of the MSV are in Bulgarian, but Kocho does not use any Bulgarian MSV. The differences in the knowledge and use of the Romani MSV by the two children are statistically significant: $t(242)=4.81$,

Graph 2. MSV in Romani and in Bulgarian

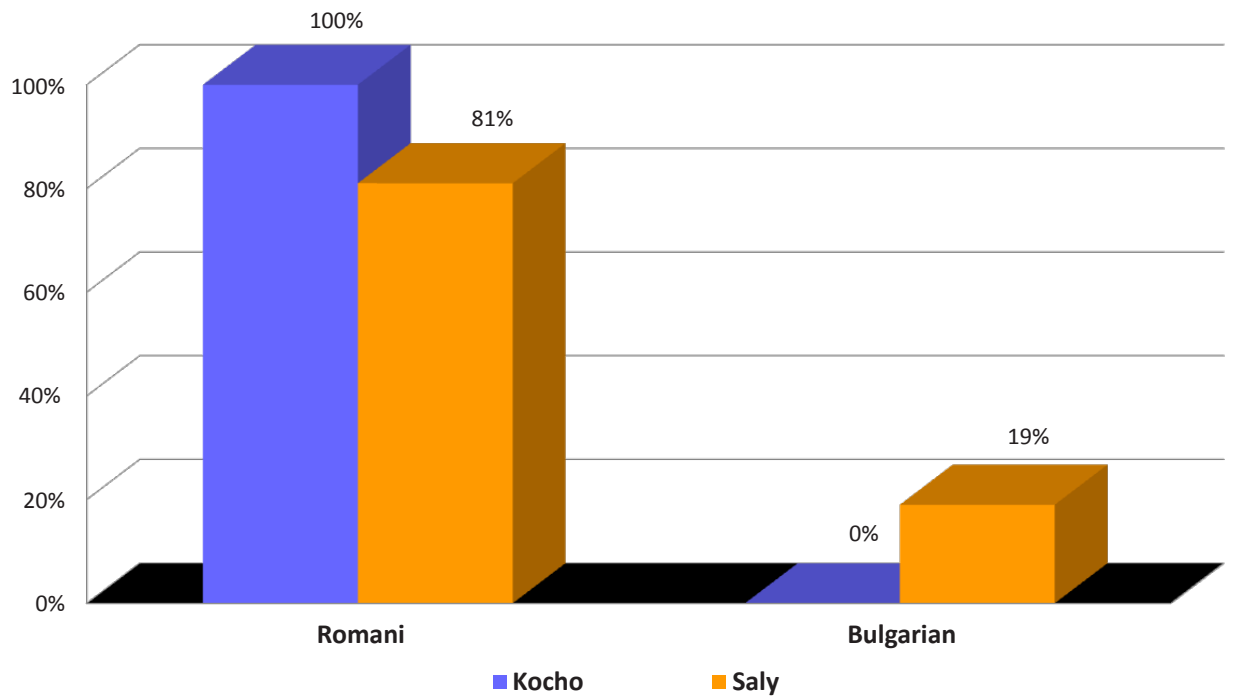


$t$-critical $=3.34(p<0.001)$. Kocho has much better knowledge of the mental state verbs in Romani and this will help him to understand mental states of other people at an earlier age.

\section{Study 2. Bates-MacArthur Communicative Development Inventories (CDI) in Romani}

In a pilot study, 40 Roma parents who have children between 8-16 months and 16-30 months were interviewed with CDI- 1 and CDI-2. The CDIs were translated and adapted into Romani spoken in Sofia. Twenty parents with children 8-16 months old and 20 parents with children 16-30 months old were the object of the study. The results show that Roma children have typical language development in learning different parts of Romani grammar.

Graph 3 shows the results for the verbs used by the two groups of children according to the parents' report.

Graph 3. Verbs in Romani in \%

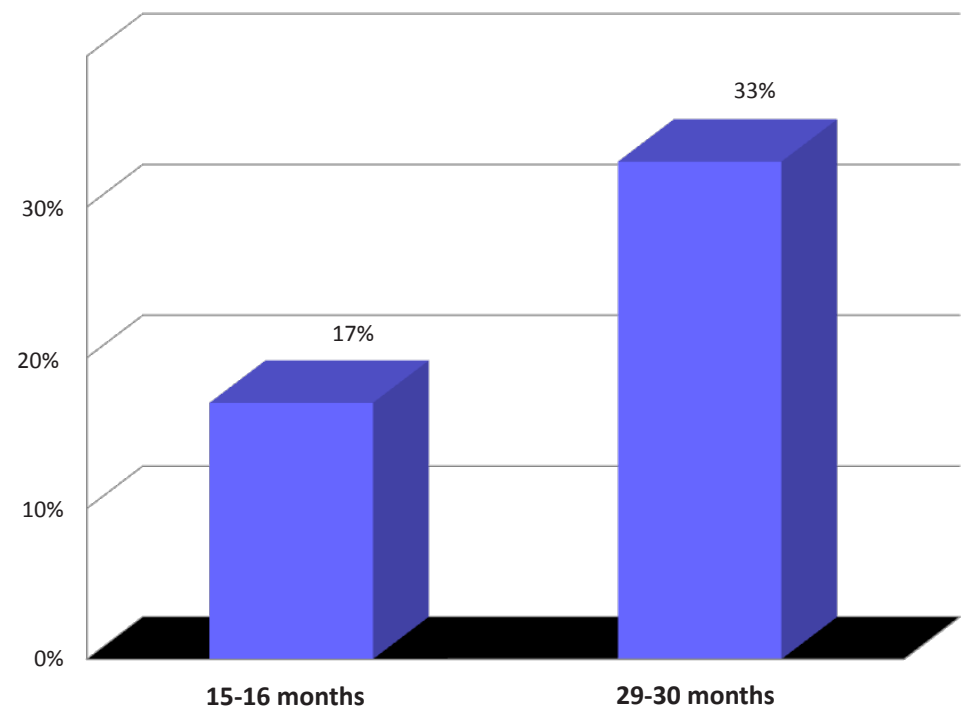

The graph clearly shows that as the children's age increases, there is greater use of verbs in Romani. The differences between the two groups are statistically significant: $t(48)=2.64, t$-critical $=2.60(p<0.01)$. Older children are better at using Romani verbs. 
Graph 4. Use of wh- words in Romani

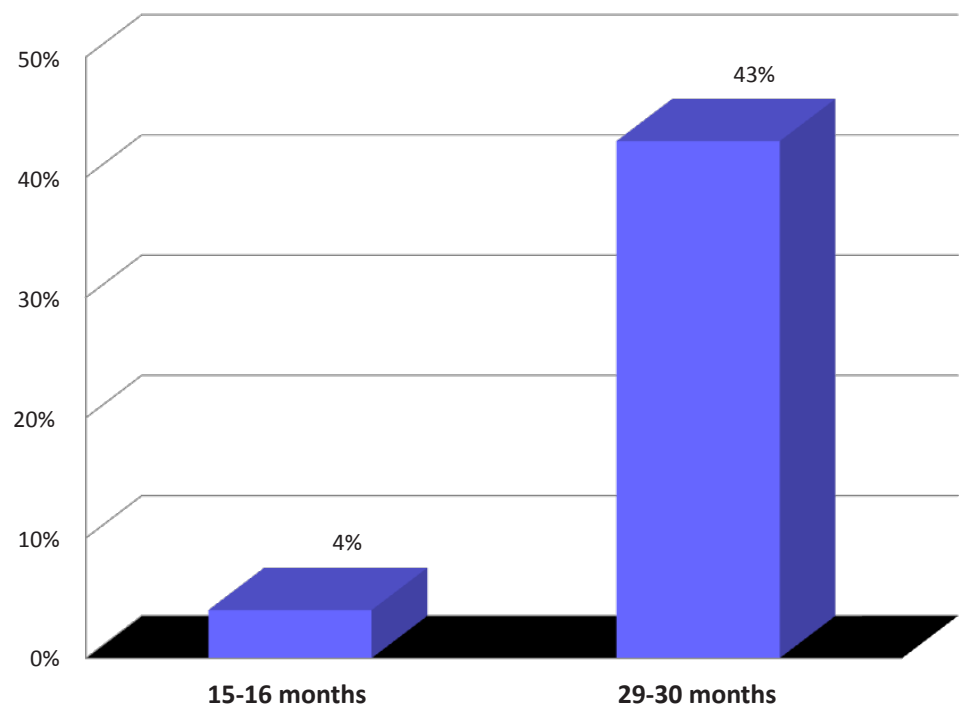

What are the wh-words in the Romani language? The results are presented in graph 4.

It is obvious that the younger children are not as good as the older children. The younger children (15-16 months old) use just $4 \%$ of wh-words in Romani. The older children (29-30 months old) use $43 \%$ of wh-words. The differences between the two groups in the use of wh- words are very significant: $t(45)=7.28$, $t$-critical $=3.34(p<0.001)$

The study shows that by the age of 30 months, in their language Roma children use pronouns, prepositions, conjunctions and adverbs, together with nouns, verbs and wh-words. This shows that Roma children follow the development of any typically developing child learning any language as a mother tongue.

\section{Study 3. Communicative competence}

The study encompassed 130 children (120 in kindergarten and 10 in primary school). The children from the kindergarten, who were divided into three age groups (Group 1: 4-5 years old, Group 2: 5-6 years old, and Group 3: 6-7 years old), and one group of 10 children from grade 4 (10-11 years old) of primary school, were tested with different tests measuring comprehension and production in Romani.

The children were given five verbal tests which are not standardized for the Romani language. The tests were translated and adapted from English: 
1. One-word receptive test

2. One-word expressive test

3. DELV - Diagnostic Evaluation of Language Variation (Seymour, Roeper, \& de Villiers, 2005)

- Subtest for verbs

- Subtest for wh-questions

- Communicative role-taking

- The children's results are presented below.

\section{One-word receptive test}

The children are shown four pictures per page and the researcher says a word. The child has to show which picture matches the word said by the researcher. The results are given in Figure 1:

Figure 1. Results from one-word receptive test

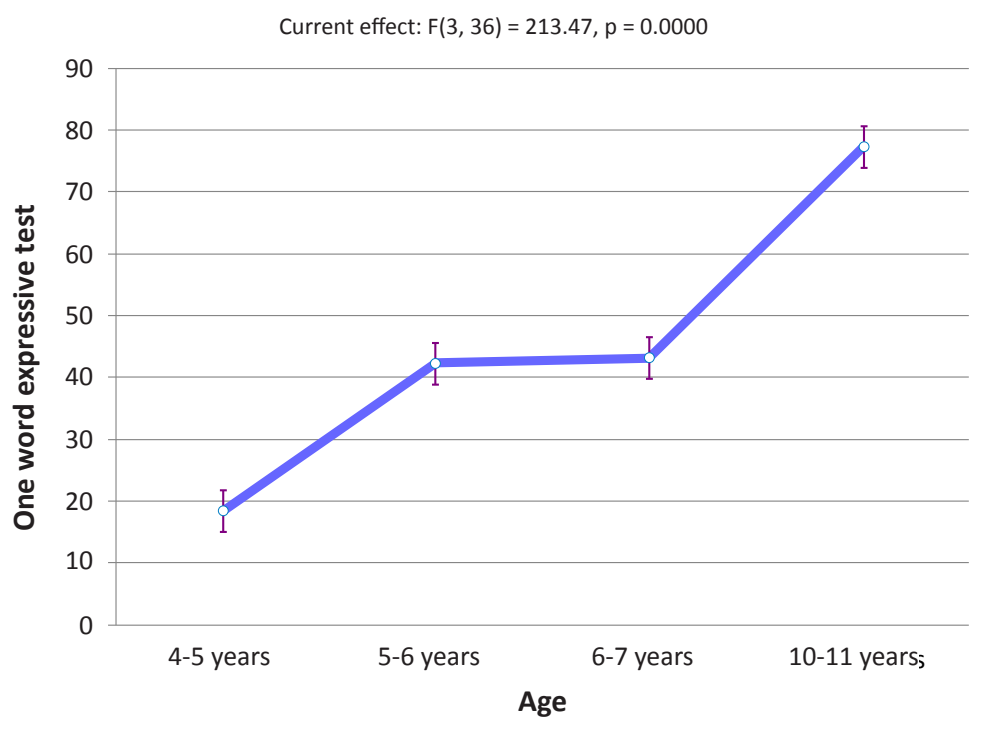

As the graph shows, there are differences between the four groups in comprehension of the words. The older children understand the words better than the younger children. There are no differences in the results between children 5-6 years old and 6-7 years old. The differences between the groups are statistically significant: $F(3,36)=213.47, p<0.0000$. 


\section{One-word expressive test}

The children are shown pictures of different objects and they have to name them. The results are shown in Figure 2.

Figure 2. Results from one-word expressive test

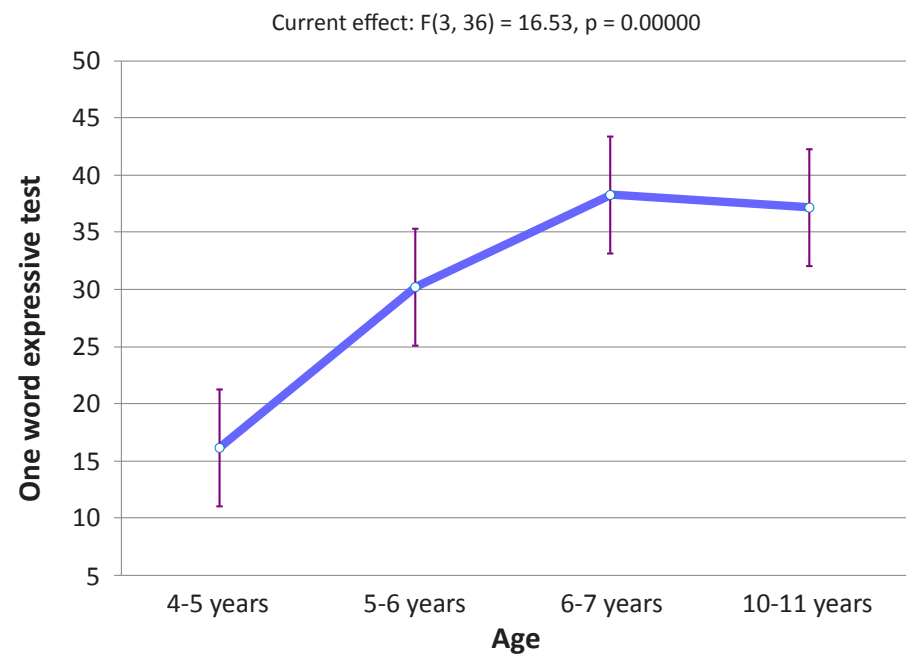

Figure 2 presents the children's results in the performance of the test and shows that there are significant differences between the groups: $F(3,36)=16.53$, $p<0.0000$. The results of children 4-5 years old are the lowest, and the results of the older children are higher. In this test, children 10-11 years old have results similar to those aged 6-7. It is obvious that the knowledge of 10- to 11-year-old children of the Romani lexicon did not increase. They have the same level of knowledge of the Romani lexicon as children 6-7 years old.

Three subtests from DELV (Diagnostic Evaluation of Language Variation) were used for testing the same groups of children. The tests are on knowledge of verbs, asking questions and communicative role-taking.

\section{Verbs}

The children are shown pictures and are given a proposition with each picture. However, the proposition is not finished. At the end of the proposition, there is a place where the child has to use a verb. A second sentence with the same picture has to be used, but the verb which has to be added has to be different (the opposite). The results from this subtest are shown in Figure 3. 
Figure 3. Knowledge of Verbs

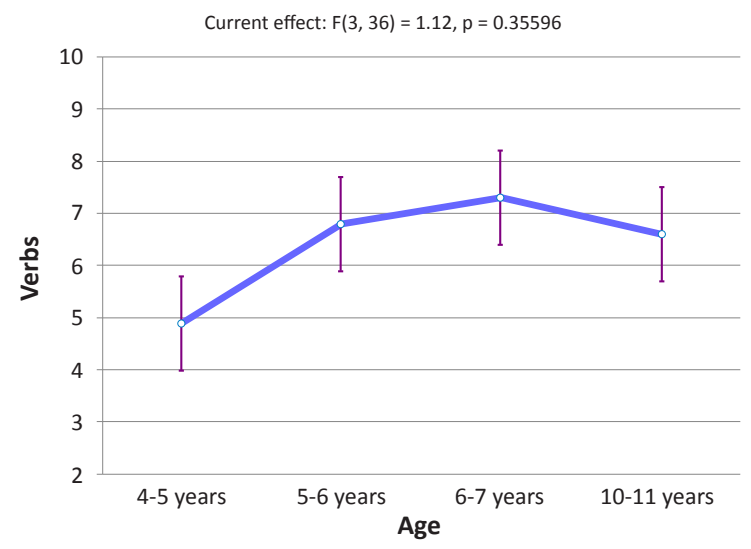

Figure 3 shows that the results between the four age groups are not statistically significant: $F(3,36)=1.11 ; p<0.01$. The biggest differences are between the groups of children 4-5 and 5-6 years old, while the 10- to 11-year-olds again show very low results, similar to the results of children 6-7 years old.

\section{Asking Questions}

The children are given pictures where it is not shown what the person is doing. The child has to ask what the person in the picture is doing. The next page shows what the person is really doing. The results from this subtest are shown in Figure 4.

Figure 4. Asking questions

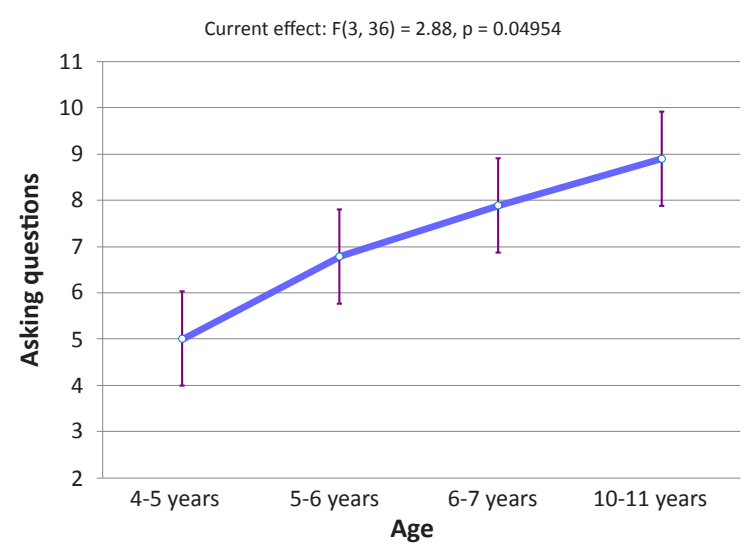


Figure 5. Communicative role-taking

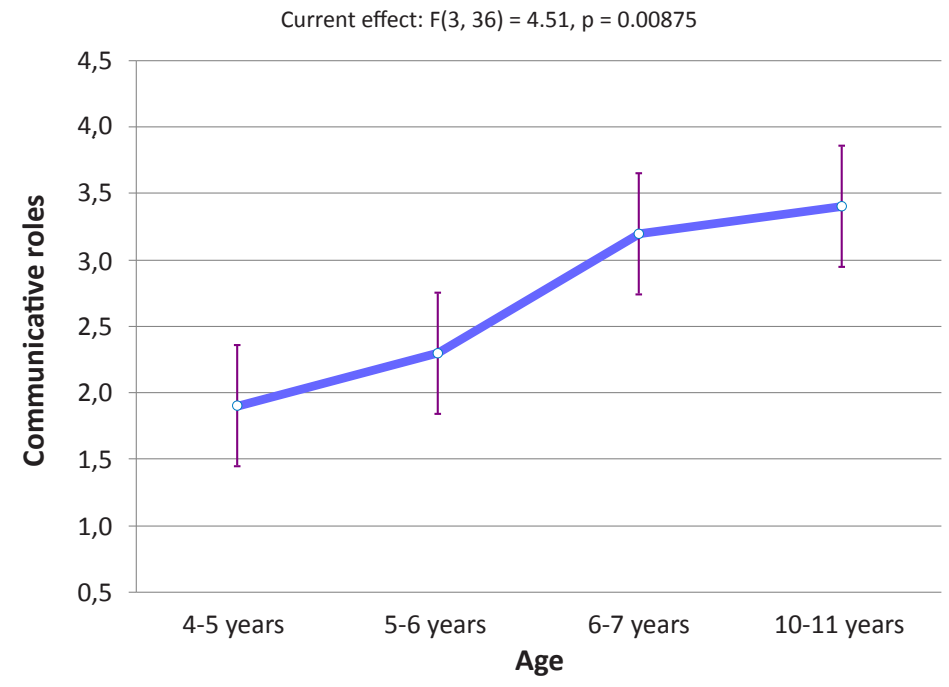

As shown in Figure 4, children's ability to ask questions increases from age group 1 up to age group 4. The differences between the groups are statistically significant: $F(3,36)=2.87 ; p<0.05$

\section{Communicative role-taking}

In this sub-test, the children are shown pictures and they have to tell a short story about what is happening. However, the child has to assume the role of the character from the pictures and tell the story from his/her point of view. The results from this subtest are shown in Figure 5.

Figure 5 shows that there are significant statistical differences between the groups: $F(3,36)=4.51 ; p<0.0087 ; p<0.01$. The results of the children increase from the youngest group to the oldest one. The older children are much better than the younger children at assuming roles.

\section{Discussion and Conclusions}

As one can see from the studies presented in the paper, Roma children growing up in bilingual conditions first acquire the basics of Romani language as their mother tongue. At the same time, they start to learn a second language from a very early age - in this case Bulgarian, which is the official language of Bulgaria, but in some other cases Roma children also learn another minority language and they actually grow up trilingual. 
The research questions asked at the beginning of the paper actually show that Roma children learn the grammar of the Romani language; Romani has its own structure, although the language is not a standardized or codified language. All the grammatical categories are present in the grammar of Romani in its rich range of dialects, which is an Indo-European language from the family of new Indian languages related to Sanskrit and Hindi.

The studies presented here focused mainly but not only on the acquisition of verbs and it is obvious, as proven in the first study, the second study and partly in the third study, that verbs play an important role in understanding the social relations between people, particularly mental state verbs.

Another important grammatical category is wh- questions, because Romani has the possibility to have double wh-words in a question sentence, like Kon so xal? (Who eats what?). Children from a very early age know which wh-question to answer and in Romani, usually the second wh-word is answered.

All the knowledge of children on correctly using verbs and correctly asking questions is used in different communicative roles. Life in a community and in the extended family actually gives the children great experience with learning the complex grammatical structures from a very early age and using this knowledge in their everyday life.

Although the three studies are not connected among themselves, they are interrelated and show how children develop different grammatical categories. It is clear that children understand and produce nouns and adjectives; they have knowledge of verbs, they can ask and answer questions, they can assume roles in different communicative situations. In general, Roma children follow the path of all normally developing children learning any language around the world. It seems that language develops until the age of 6-7, but in the period from 6-7 to 10-11 years, it seems that children do not develop their knowledge in Romani so much. It may appear that entering primary school somehow stops further development of Romani, because in some categories children aged 10-11 years showed the same results as children in the 6-7 age bracket. This is a sign that in the early primary school years Romani should be introduced as a mother tongue in the school curriculum, which will help Roma children to keep the mother tongue while learning the second language, and in this way the children will avoid becoming semi-linguals, with poor or stunted proficiency in their home language L1 - but rather achieve good dual functional knowledge as balanced bilinguals.

\section{References}

Babska, Z. \& Shugar, G.W. (1984). Idea dwupodmiotowości interakcji dorosły-dziecko w procesie wychowania w pierwszych latach życia [Idea of dual agentivity of adult-child interaction in early education]. Roczniki Filozoficzne KUL, $32(4), 17-48$. 
Gleason, J. Berko (1975). Fathers and other strangers: Men's speech to young children. In D. Dato (Ed.), Developmental Psycholinguistics: Theory and Applications (pp. 289-297). Georgetown University Press.

Gleason, J. Berko (1992). Language Acquisition and Socialization. University Lecture. Boston: Boston University Press.

Kyuchukov, H. (1998). Acquisition of Romani morphology. Grazer Linguistische Studien, 51, 83-94.

Kyuchukov, H. (1999). Early acquisition of Romani (Gypsy) language. In M. de G., Pinto, J. Veloso, B. Maia (Eds.), Proceedings from the $5^{\text {th }}$ International Congress of the International Society of Applied Psycholinguistics (pp. 329-337). Porto: Porto University Press.

Kyuchukov, H. (2001). Razvitie na detskiya romski i detskiya turski bilingvizam v Bulgaria [Development of Romani and Turkish Children's Bilingualism in Bulgaria]. Sofia: IKTUS.

Kyuchukov, H. (2003). Moite parvi dumi na romski [My first words in Romani].

In H. Kyuchukov (Ed.), Detska rech i bilingvizam [Child Language and Bilingualism]. Sofia: Diversity Press.

Kyuchukov, H. (2005). Early socialization of Roma children in Bulgaria. In X.P.

Rodriguez-Yanez, A.M. Lorenzo Suarez, \& F. Ramallo (Eds.), Bilingualism and

Education: From the Family to the School (pp. 161-168). Muenchen: Lincom Europa.

Kyuchukov, H. (2007). How do children learn Romani syntax? In P. Ilieva-Baltova \& K. Petrova (Eds.), Psycholinguistic Studies (pp. 271-281). Sofia: Riva Publishers.

Kyuchukov, H. (2010). Romani language competence. In J. Balvin \& L. Kwadrants

(Eds.), Situation of the Roma Minority in Czech, Hungary, Poland and Slovakia (pp. 427-463). Wroclaw: Prom.

Kyuchukov, H. (2011). Cognitive development and Romani language acquisition in socio-cultural context. In J. Balvin, M. Kowalczyk, \& L. Kwadrans (Eds.), Situation of the Roma Minority in the Czech Republic, Hungary, Poland and Slovakia. Vol. 2 (pp. 87-102). Wroclaw: Prom.

Kyuchukov, H. (2014). Romani language assessment of Roma children. Journal of Language and Cultural Education, 2 (2), 52-64.

Kyuchukov, H. \& de Villiers, J. (2009). Theory of Mind and evidentiality in RomaniBulgarian bilingual children. Psychology of Language and Communication, $13(2), 21-34$.

Kyuchukov, H. \& de Villiers, J. (2014). Roma children's knowledge on Romani. Voprosyi psicholingvistiki - Journal of Psycholinguistics, 1 (19), 58-65.

Reger, Z. \& Gleason, J. Berko (1991) Romani child-directed speech and children's language among Gypsies in Hungary. Language in Society, 20 (4), 601-617.

Reger, Z. (1999). Teasing in the linguistic socialization of Gypsy children in Hungary. Acta Linguistica Hungarica, 46 (3-4), 289-315. 
Ruffman, T., Slade, L. \& Crowe, E. (2002). The relation between children's and mother's mental state language and Theory of Mind understanding. Child Development, 73 (3), 734-751.

Schieffelin, B.B. (1985). The Acquisition of Kaluli. In: D. Slobin (Ed.), The Crosslinguistic Study of Language Acquisition. Vol. 1 (pp. 525-594). Hillsdale, NJ: Lawrence Erlbaum Associates.

Seymour, H.N., Roeper, T., \& de Villiers, J.G. (2005). DELV-NR (Diagnostic Evaluation of Language Variation) Norm-Referenced Test. San Antonio, TX: The Psychological Corporation.

Shugar, G.W., Bokus, B., \& Smogorzewska, J. (2013). From Reference Situation to Narrative Text. Piaseczno: Studio Lexem. 